\title{
Sales Force - Customer Relationship and Ethical Behaviours in the Nigerian Banking Industry: A Synthesis
}

\author{
Nebo, Gerald Nwora ${ }^{1}$, Dr. Moguluwa Shed Chinwuba ${ }^{2}$ \\ ${ }^{I}$ Department of Marketing, Enugu State University of Science and Technology, Enugu State, Nigeria. \\ ${ }^{2}$ Department of Marketing, University of Nigeria, Enugu Campus, Enugu State, Nigeria.
}

\begin{abstract}
This study examined 'Sales force - Customer Relationship and Ethical Behaviours in Nigerian Banking Industry. The objectives include: to assess the differences in the ethical behaviours of bank sales force; to determine the effects of sales quotas, social ties and personal moral judgment on salespeople's ethical behaviours; to identify the congruence between bank salespeople's and customers' perceptions of ethical behaviours. Survey research design and six banks were used for the study. 203 bank salespeople and 150 customers were sampled. Convenience sampling technique was used for selecting respondents. Questionnaire was used for data collection. The reliability of the research instrument yielded 0.83 co-efficient using Cronbach Alpha test. ANOVA, Regression Analysis and Pearson's Product Moment Correlation were used to test hypotheses. Findings show a significant difference in the salespeople's ethical behaviours; sales target, social ties and low personal moral judgment are responsible for salespeople's unethical behaviours; there is a significant congruence between the salespeople's and customers' perceptions of ethical behaviours and there is a strong negative influence of bank's corporate code of ethics on salespeople's ethical behaviours. This study is a case of ethical dilemma. The study recommends that the bank management should adopt discretional measures in approaching ethical issues
\end{abstract}

Keywords: Sales Force, Ethics, Behaviour, Customer-Relationship, Bank.

\section{Introduction}

Competition in the Nigerian banking industry has forced most banks to engage in different strategies to attract customers (Ojikutu et al, 2013). One of the strategies that has gained prominence in recent time in the Nigerian banking industry is customer relationship marketing. Because of its importance, salespeople are hired to foster and nurture this all important relationship. Borys and Jemison (2009) refers to relationship marketing as all marketing activities directed towards establishing, developing and maintaining successful relationship with customers. Research evidence shows that customer relationship marketing is profitable to a firm and improves corporate performance through customer loyalty and retention.

Agarwal and Malloy (2009) suggest that salespeople critically affect the formation and sustainability of customer relationships. However, the fact remains that the ethics of those engaged in selling profession have often been questioned. This is why Seevers et al (2010) suggest that whoever one hires for sales job is important but perhaps not as important as what he/she is recruited to do and how to do it after being hired. Ethicality/ unethicality of the sales force can destroy or improve customer relationship. Studies show that customers' perceptions of salespeople's ethical behaviours significantly affect buying intentions. The more unethical a salesperson's behaviour is perceived to be, the lower the buyer's intention to purchase from the firm employing that salesperson (Churchill et al, 1997). Therefore to improve bank performance through relationship marketing, there is the need to ascertain ethical conducts of the bank sales force members in their dealing with customers.

\subsection{Statement Of The Problem}

Ethical behaviour of the sales people is a known correlate of customer buying intentions and organizational performance (Spiro et al, 2005). Unethical buying practices often results to actual or potential harm to customers giving rise to loss of sales, customers' loyalty and loss of patronage as well as organizational profits over time (Churchill et al, 1997). Research studies show that salespeople in the Nigerian banking industry engage in different forms of unethical practices such as offering of bribes or gifts to induce sales, making sales calls at odd hours, giving of false or misleading information and giving preferential treatments to customers, dating of customers, engaging in high pressure selling tactics, hanging out and entertaining of customers which provoke undue influence on customers' purchase decision. For instance, Akenbor and Imade (2011) examined "Sales Targets and Ethical Behaviour of Marketing Executives in the Nigerian Banking Industry" and discovered that salespeople engage in indecent dress mode and hard selling practices in a bid to meet high sales targets set for them by managers. In order to solve the identified unethical problems of the salespeople, build long -term customer relationship, maintain customers' trust, satisfaction and cooperation; there is the need to ascertain the quality of sales force-customer relationship and ethical conducts in the Nigerian banking industry. 


\subsection{Objectives Of The Study}

The objectives of the study include;

1. To assess the differences in the ethical behaviours of sales force in the selected banks.

2. To determine the effects of sales quotas, social ties and personal moral judgment on salespeople's ethical behaviours.

3. To identify the congruence between bank salespeople's and customers' perceptions of ethical behaviours.

4. To ascertain the influence of banks' corporate code of ethics on salespeople's ethical behaviours.

\subsection{Research Hypotheses}

$\mathrm{H}_{01}$ :There is no significant difference in the ethical behaviours of the sales force in selected

Nigerian banks

$\mathrm{H}_{02}$ :Sales quotas, social ties and bank salespeople's personal moral judgment do not have any significant effect on salespeople's ethical behaviours.

$\mathrm{H}_{03}$ :There is no significant congruence between the bank salespeople's and customers' ethical perceptions.

$\mathrm{H}_{04}$ : The banks' corporate code of ethics do not have any significant influence on salespeople's ethical behaviours.

\subsection{Conceptual Meaning Of Bank Sales Force}

\section{Review Of The Literature}

In mainstream marketing, the term sales force refers commonly to a group of employees whose job is basically selling (Badovick, 2010). Selling in this case refers to the activity of giving or handing over something of value to someone in exchange for money. It also means to persuade someone of the merits or benefits of something which could be a product, idea or service in order to exchange it for money or other values (Futrell, 2003). In most business places, the term sales force are interchangeably used as salespeople, sales executives, salesmen, sales representatives, sales engineers and salespersons. Therefore, bank sales force are individuals employed to represent banks and to sell its products to actual and potential customers..

\subsection{Meaning Of A Customer}

Webster's Ninth New Collegiate Dictionary defines a customer as one that purchases a commodity or services. Also, the Oxford Advanced Leaner's Dictionary views a customer as a person or an organisation that buys something from a shop/store or business. Similarly Butler (1996) sees a customer as someone who uses, recommends or retains some varying influence over purchase decision. Continued customer patronage ensures that a firm remains in business and achieves its goals and objectives. The ultimate goal of all businesses as "Written in tablets of stone" is to satisfy the customers otherwise there will be no business.

\subsection{Customer Relationship Management [Crm] And Relationship Marketing [Rm]}

Customer Relationship Management is a subset of relationship marketing which refers to the process of identifying, developing, maintaining and terminating relational exchange with customers in order to enhance performance. Berry (2005) has a strategic viewpoint concerning customer relationship management. He has stressed that attracting new customers should be viewed only as an intermediate step in the marketing process and that developing closer relationship with these customers and turning them into loyal ones should be equally important aspects of marketing. Thus, he proposed that Relationship Marketing should be seen as attracting, maintaining, and - in multi-service organizations - enhancing customer relationships. Thus the major emphasis of relationship marketing is to keep and improve current customers rather than acquiring new ones. Gronroos (1994) identified five distinct factors which build customer relationship as service quality, customer satisfaction, commitments, opportunism and social bond. Customer relationship leads to customer loyalty, retention and profitability.

\subsection{Meaning of Sales Force - Customer Relationship'}

In this present dispensation, particularly in the era of hyper-competition, marketers especially the salespeople in most business organizations are usually forced to be more concerned with customer retention and loyalty (Dick and Basu, 2004; Bionget al., 2006). The realization of most marketers is that, it costs less to retain customers than to compete for new ones (Bharadwaj, 2004). In addition, several marketers are concerned with keeping customers for life rather than with only making a one-time sale (Anderson and Narus, 2011). Therefore, the concept of 'Sales Force - Customer Relationship' as used in this current study, connotes such relationship marketing as defined by Baker (2008) which is the integrated effort of salespeople toward identifying, maintaining, and building up a network with individual customers and to continuously strengthening the network for the mutual benefit of both parties, through interactive, individualized and value-added contacts over a long period of time. In Nigerian banking industry, a salesperson is assigned to each Account (i.e. customer) who keeps in touch with the customer always to ascertain and provide solutions to their problems. 


\subsection{Concept Of Ethics}

The term 'ethics' means - the branch of philosophy that involves systematizing, defending and recommending concepts of right and wrong conduct, and often addressing disputes of moral diversity (Brower and Shrader, 2000). The term originates from the Greek word ethikos from ethos, which means "custom", or "habit" (Cullen et al., 2003). Ethics are the moral principles and values that govern the actions and decisions of an individual or group (Berkowitz et al: 2007). They are moral principles, practices and values that guide a firm's behavior. Thus to act in an ethical fashion is to conform to some standard of moral behavior. Ethical principles reflect the religious, social, cultural values and norms of a society.

What then is selling ethics? They refer to the moral principles and values that guide behavior within the field of selling and sales management. Selling ethics cover issues such as the avoidance of bribery, deception, hard (pressure or coercion) selling, reciprocal buying, preferential treatments, the use of promotional inducements to the retail trade, slotting allowances and pyramid selling (Jobber and Lancaster, 2009).

\subsection{Measures or Dimensions of Banks' Sales Force Ethical Behaviours in Their Dealings With Customers.}

Sales force ethical behaviours refer to the way salespeople's conduct while they are at work, including their senses and perceptions of right and wrong occupational conducts (Adnan et al, (2013). It involves ethical practices of the salespeople in their business relations with customers and companies they represent. Dimensions of ethical behaviour or conducts of the salespeople in their dealings with customers are: Bribery and gifts to customers; chatting and making sales calls at odd hours; giving false and misleading information to customers; dating customers, hanging out and entertaining customers, hard selling and reciprocal buying.

Bribery/Gifts: Bribery is the act of giving payments, gift, gratification or other inducements to secure a sale. Such actions are thought to be unethical because they violate the principle of fairness in commercial negotiations. The problem with gift or bribery is that it makes an undue influence on customers' purchase decisions. Some scholars contend that a reasonably priced and tastefully selected gift can express appreciation for a customer's business. However the problem lies in deciding the boundary between what is reasonable or tasteful gift. Some gifts are clearly bribes while some are not.

Chatting and making sales calls at odd hours: Chatting and making sales calls at odd hours could be a disturbance and interference with customer's privacy and therefore unethical.

False and Misleading Information: Salespeople fall into temptation to mislead the customer in order to secure an order. It is important that salespeople provide their customers with all of the information that enables them to make informed decisions. But sometimes they give misleading information to customers. The deception may be exaggeration of product benefits, outright lying or withholding information that would lessen the product appeal.

Dating the customers: Dating the customer is considered unethical because it is similar to reciprocal buying. This type of relationship tend to make an undue influence on customer buying decision. It forces the customer to buy products he or she would ordinarily not buy.

Entertainment: Entertainment has similar influence with gift/bribe. Business entertainment is definitely a part of sales work and large portion of the expense money is devoted to it. However, scholars argue that a certain level of entertainment can result to undue influence on customers' purchase behavior and therefore should be used with caution.

Hard Selling: Personal selling is often criticized for use of high pressure or hard selling tactics to secure a sale. Salespeople are accused of using "sweet mouth" to induce customers to take hasty decisions on a complicated and complex purchases involving a very high expenses. Such purchases do not allow the customers to give a careful thought over the products that best satisfies their needs. Customers are pushed into buying such products only to feel high dissonance after purchases.

\subsection{Factors That Moderate Sales Force Ethical Behaviour}

A plethora of studies on corporate ethics have hypothesized five most commonly ethical factors that affect salespeople's ethical behaviour with customers to include: instrumental ethical climate (including selfinterest and company profit), caring ethical climate (including friendship and team interest), personal morality ethical climate, company rules and procedure and laws and professional codes (De Coninck, 2003). More so, three antecedents of ethical climate including individual, organizational and environmental antecedents have also been suggested to shape the ethical behaviours of salespeople toward their customers (Weeks and Nantel, 1992). Although many factors have been hypothesized to influence the ethical practice of the salespeople, this study concentrates on four major factors mostly found in literature viz: sales quota/targets, social ties, personal moral judgment and corporate code of ethics. 


\section{Pressure to Attain Sales Quota/Targets}

Salespeople's ethical codes may bend when faced with hard conditions or pressures from customers, families, competition and boss to meet targets or quotas (Nebo, 2016). According to Spiro et al (2005), in a survey of salespeople, nearly half of the respondents admitted taking part in some illegal or unethical activity such as deceiving customers as a result of pressure to meet sales targets. Salespeople believe that not paying bribes/gifts either in cash or kind might put them and their firms at a competitive disadvantage. However, in Ojikutu et al (2013), perceived difficulty in sales quota attainment was found to have negative relationship with ethical behaviour of the salespeople. Based on these argument, we therefore, hypothesize sales target as a moderator of salespeople's ethical behaviours.

\section{Social Ties/Relations}

A number of studies have been done to investigate the role of social or friendly ties on ethical behaviour of salespeople. For instance, Seevers et al (2010) argued that employees in most companies are complicit and that the social ties between individuals encourage ethical misconduct. They emphasized that the social ties that link a salesperson to clients especially through social network devices such as facebook, WhatsApp, Instagram, Twitter, SMS etc. or hanging out with clients for lunch or night club are critical factors to ethical behaviours. Based on this assertion, we hypothesize social ties as factor that moderate ethical behaviours of the salespeople.

\section{Salesperson's Personal Moral Judgment}

A number of studies on corporate ethics and sales force management suggest that a salesperson's individual characteristics such as demographics (e.g. gender and age) and personality variables (e.g individual moral values and moral ethical development) moderate salespeople's ethical behaviour. Most salespeople have their own standard of personal ethics and they usually abide by these standards in dealings with their firms and customers. However, the problem with personal moral judgment of the salesperson is that they vary among the salespeople with different ethnic and religious background. Personal moral judgment of a salesperson is highly influenced by religions, cultural, legal, societal norms and values. Thus actions perceived by one salesperson as ethical may be perceived by another as unethical. Based on these assertions, we hypothesize that: (1) there is a significant difference in the ethical behaviours/ perception of the salespeople (2) personal moral judgment of the salespeople have moderating effects on the ethical behaviours of the salespeople.

\section{Corporate Codes of Ethics}

Of all ethical climate variables, investigations into the effects of corporate codes of ethics on salesperson ethics dominate the literature. Codes of ethics are formally written and explicit policies intended to guide employee and corporate behavior by establishing the boundaries of ethical behavior. The efforts taken to communicate and educate employees about an organizations code of ethics can enhance the ethical climate by specifying the organization's ethical values and the behaviors that are expected within the organization (Cotte $e t$ al., 2006). The literature provides supporting evidence of a positive relationship between properly communicated codes of ethics and ethical corporate behavior. The existence of organizational codes of ethics has been found to be associated with higher levels of salesperson ethical behavior (Weeks and Nantel, 1992). However, there are instances when codes of ethics have been less effective as antecedents to ethical behavior. Ethics code familiarity and usefulness among managers' declines as organizational turbulence and uncertainty increase (Cotteet al., 2006). Based on these assertions, we hypothesize that banks' corporate code of ethics have significant influence on salespeople's ethical behaviours

\subsection{Theoretical Frameworks}

Two popular theories have been adapted from extant related studies for understanding how sales force make ethical decisions while dealing with clients. These are: General Theory of Marketing Ethics and Social Learning Theory.

General Theory of Marketing Ethics propounded by Hunt and Vitell (1986), assumes that both deontological and teleological evaluations are engaged by salespeople in making ethical decisions. Deontological ethics employs the rights principle and justice principle in determining ethical behaviour. The right principle is based on the rights of an individual in a society such as the right to information and the right to expression. Based on this, any action that infringe on the individual's basic right is deemed unethical. The justice principle is based on "fairness" and biblical injunction "Do unto others as you would like others to do unto you". Justice principle focuses on retributive justice whereby the wrong doer is punished proportionately to the wrongdoing provided it was committed knowingly and freely and compensating justice whereby the injured party is restored to his or her original position. Where firm demotes a salesperson for telling lies to a customer or compensates a customer for missing a delivery schedule promised by its sales representative are examples of justice principle 
Teleology ethical evaluation is based on the overall consequences of an action on the society in judging what is right or wrong. It requires that a social cost/benefit analysis be conducted for the contemplated action. All benefits and costs to all persons affected by the particular act need to be considered and summarized as the net of all benefits minus all costs. If the net results is positive, the act is morally acceptable; if the net result is negative, the act is not (Churchill et al, 1997).

General Theory of Marketing Ethics emphasizes that both deontological and teleological ethics should be combined in determining ethical behaviour.

The Social Learning Theory proposes that employees learn company norms by observing and imitating other employees. This vicarious learning also occurs when others are rewarded or punished. DeConinck (2003) found that when unethical behavior was punished, observers expected the same infraction to be punished in the future and perceived punishment as being the most appropriate disciplinary action. The implication of Social Learning Theory is that when employees expect that unethical behavior will be consistently punished, they are more likely to refrain from such behavior.

\subsection{Empirical Reviews}

Existing related studies are examined in this section. Ojikutuet al. 's (2013) assessed the Relationship Between Sales Quotas and Moral Judgment of Insurance Salespersons: the Moderating Effects of Personal Moral Values, Quota Failure Consequences, and Corporate Ethical Climate, using survey research design method. Findings revealed that, the proposed negative relationship between perceived quota difficulty and moral judgment is not significant; which implies that, assigning difficult sales quota may not necessarily result in ethical compromise by salespersons. Seeverset al., (2010) did a study titled A Social Networks Perspective on Sales Force Ethics and discovered that ethical behavior is adjudged not merely a function of personal or corporate values rather; ethical misconduct is often a thing of social activity.

Weeks and Nantel (1992) also did a study titled Corporate Codes of Ethics and Sales Force Behaviour, findings revealed that, a well communicated code of ethics can be related to ethical sales force behavior, high job satisfaction and job performance. In Adnan et al's(2013) study, the authors sought to know what actually shapes the ethical behavior of sales team using the banking sector of Pakistan as a case study. They concluded that: (i) leader's characteristics, organizational characteristics and sales force characteristics have positive impact on the sales force ethical behavior; (ii) autocratic leadership style and job security are negatively related with ethical behavior development. Cotteet al., (2006) also did a study titled Ethical Climate: Management's Role in Unethical Sales force Behaviour. Findings revealed that ethical climate, as communicated via a sales manager's approval of certain behaviors, has a direct and important impact on salesperson behavior.

\section{Methodology}

This study examined "Sales Force-Customer Relationship and Ethical Behaviours in the Nigerian Banking Industry: A Synthesis. Survey research designed was adopted for the study. Six Nigerian banks were selected for study. These include: First Bank and United Bank for Africa Plc representing old generation banks; GTBank and Zenith Bank representing new generation banks and Key Stone Bank and Heritage Bank representing Struggling banks. Altogether 203 salespeople and 150 customers were selected for study using Taro Yamane's formular. Convenience sampling procedure was adopted for selecting the salespeople and customers studied. Data was collected by means of structured questionnaire. Crombach Alpha test was used for ascertaining the reliability of the research instrument. The Cronbach Alpha test yielded a reliability co-efficient of 0.83 which showed that the instrument is reliable using a benchmark reliability score of 0.70 (Nunnally and Bernstein, 1994). One-way Analysis of Variance, Post-hoc Test, Multiple Linear Regression Analysis and Pearson's Product Moment Correlation were used for analysis of data and testing of hypotheses.

\section{Data Analysis And Findings}

Out of the 203 copies of questionnaire administered on the bank salespeople, $163(80.3 \%)$ were returned, while $122(81.3 \%)$ copies where returned out of 150 issued to customers.

\subsection{Test Of Hypotheses \\ Hypothesis one}

$\mathrm{H}_{0}$ :There is no significant difference in the ethical behaviours of the salespeople in selected Nigerian banks $\mathrm{H}_{1}$ :There is a significant difference in the ethical behaviours of the salespeople in selectedNigerian banks Six items were used to measure the ethical/unethical behaviour of the banks' salespeople studied. These include: Q1 - Offering of Bribes/gifts to customers

Q2 - Have or does not have specified time for calling clients

Q3 - Making sales calls at odd hours 
Q4 - Giving false and misleading information to customers

Q5 - Dating customers.

Q6 - Hanging out with and entertaining customers.

Table 1: Perceptual Differences among the Bank Salespeople's Ethical Behaviour

\begin{tabular}{|l|l|l|l|l|l|}
\hline & Sum of Squares & Df & Mean Square & F & Sig. \\
\hline Between Groups & 1879.029 & 5 & 375.806 & 100.106 & .000 \\
\hline Within Groups & 589.388 & 157 & 3.754 & & \\
\hline Total & 2468.417 & 162 & & & \\
\hline
\end{tabular}

One-way ANOVA test result presented on Table 1 above shows that there is a significant $\left(\mathrm{F}_{\text {cal }}=\right.$ 100.106, $\mathrm{p}<0.05)$ perceptual difference among the ethical behaviours of the bank salespeople. Table 2 below further presents the post-hoc showing the Multiple Comparisons of the ethical differences existing between/among salespeople in the banks surveyed.

Table 2: Post-hoc Multiple Comparison Test of the Bank Salespeople's Ethical Behaviour

\begin{tabular}{|c|c|c|c|c|c|c|}
\hline \multirow[t]{2}{*}{ (I) Respondents } & \multirow[t]{2}{*}{ (J) Respondents } & \multirow[t]{2}{*}{ Mean Difference (I-J) } & \multirow[t]{2}{*}{ S.E } & \multirow[t]{2}{*}{ p-value } & \multicolumn{2}{|c|}{$95 \%$ Confidence Interval } \\
\hline & & & & & Lower Bound & Upper Bound \\
\hline \multirow[t]{5}{*}{ FBN } & UBA & $-7.23264^{*}$ & .50631 & .000 & -8.6935 & -5.7718 \\
\hline & GTBank & $-4.18056^{*}$ & .54356 & .000 & -5.7489 & -2.6123 \\
\hline & Zenith & $-3.03175^{*}$ & .52260 & .000 & -4.5396 & -1.5239 \\
\hline & Keystone & $-9.88889^{*}$ & .53238 & .000 & -11.4249 & -8.3529 \\
\hline & Heritage. Bank & $-8.61966^{*}$ & .53238 & .000 & -10.1557 & -7.0836 \\
\hline \multirow[t]{5}{*}{ UBA } & FBN & $7.23264^{*}$ & .50631 & .000 & 5.7718 & 8.6935 \\
\hline & GTBank & $3.05208^{*}$ & .52320 & .000 & 1.5425 & 4.5616 \\
\hline & Zenith & $4.20089^{*}$ & .50139 & .000 & 2.7543 & 5.6475 \\
\hline & Keystone & $-2.65625^{*}$ & .51157 & .000 & -4.1322 & -1.1803 \\
\hline & Heritage Bank & -1.38702 & .51157 & .079 & -2.8630 & .0890 \\
\hline \multirow[t]{5}{*}{ GTBank } & FBN & $4.18056^{*}$ & .54356 & .000 & 2.6123 & 5.7489 \\
\hline & UBA & $-3.05208^{*}$ & .52320 & .000 & -4.5616 & -1.5425 \\
\hline & Zenith & 1.14881 & .53897 & .277 & -.4063 & 2.7039 \\
\hline & Keystone & $-5.70833^{*}$ & .54846 & .000 & -7.2908 & -4.1259 \\
\hline & Heritage Bank & $-4.43910^{*}$ & .54846 & .000 & -6.0215 & -2.8567 \\
\hline \multirow[t]{5}{*}{ Zenith } & FBN & $3.03175^{*}$ & .52260 & .000 & 1.5239 & 4.5396 \\
\hline & UBA & $-4.20089^{*}$ & .50139 & .000 & -5.6475 & -2.7543 \\
\hline & GTBank & -1.14881 & .53897 & .277 & -2.7039 & .4063 \\
\hline & Keystone & $-6.85714^{*}$ & .52769 & .000 & -8.3797 & -5.3346 \\
\hline & Heritage Bank & $-5.58791^{*}$ & .52769 & .000 & -7.1104 & -4.0654 \\
\hline \multirow[t]{5}{*}{ Keystone } & FBN & $9.88889^{*}$ & .53238 & .000 & 8.3529 & 11.4249 \\
\hline & UBA & $2.65625^{*}$ & .51157 & .000 & 1.1803 & 4.1322 \\
\hline & GTBank & $5.70833^{*}$ & .54846 & .000 & 4.1259 & 7.2908 \\
\hline & Zenith & $6.85714^{*}$ & .52769 & .000 & 5.3346 & 8.3797 \\
\hline & Heritage. Bank & 1.26923 & .53738 & .176 & -.2812 & 2.8197 \\
\hline \multirow[t]{5}{*}{ Heritage Bank } & FBN & $8.61966^{*}$ & .53238 & .000 & 7.0836 & 10.1557 \\
\hline & UBA & 1.38702 & .51157 & .079 & -.0890 & 2.8630 \\
\hline & GTBank & $4.43910^{*}$ & .54846 & .000 & 2.8567 & 6.0215 \\
\hline & Zenith & $5.58791^{*}$ & .52769 & .000 & 4.0654 & 7.1104 \\
\hline & Keystone & -1.26923 & .53738 & .176 & -2.8197 & .2812 \\
\hline
\end{tabular}

From table 2 above, the ethical behaviours of First Bank salespeople is significantly different $(\mathrm{p}<0.05)$ from other banks' salespeople's ethical behaviours. They are even different from those of UBA salespeople despite that these two banks are old generation banks. Furthermore, the ethical behaviours of UBA salespeople is significantly different from other banks except Heritage Bank.Also there is no significant $(p>0.05)$ difference in the ethical behaviors of the new generation banks' [GTBank and Zenith Bank Plc] salespeople. Similarly, there is no significant $(p>0.05)$ difference in the ethical practices of the Struggling Banks' [Keystone Bank and Heritage Bank Nig. Ltd] salespeople. Overall, the ethical practices of salespeople of the three groups of banks surveyed are different from one another.

\section{Hypotheses Two}

$\mathrm{H}_{0}$ :Sales quotas, social ties and personal moral judgment do not have any significant effect on salespeople's ethical behaviours.

$\mathrm{H}_{2}$ :Sales quotas, social ties and personal moral judgment have significant effect on salespeople's ethical behaviours. 
Table 3: Model Summary

\begin{tabular}{|l|l|l|l|l|}
\hline Model & R & R Square & Adjusted R Square & S.E of the Estimate \\
\hline 1 & $.778^{\mathrm{a}}$ & .605 & .597 & 2.47736 \\
\hline a. Predictors: (Constant), Personal Moral Judgment, Sales Quotas, Social Ties \\
\hline \multicolumn{2}{|l|}{ b. Dependent Variable: Ethical Behaviour } \\
\hline
\end{tabular}

Table 4: ANOVA

\begin{tabular}{|l|l|l|l|l|l|l|}
\hline \multicolumn{2}{|l|}{ Model } & Sum of Squares & Df & Mean Square & F & Sig. \\
\hline \multirow{2}{*}{1} & Regression & 1492.585 & 3 & 497.528 & 81.066 & $.000^{\mathrm{a}}$ \\
\cline { 2 - 7 } & Residual & 975.832 & 159 & 6.137 & & \\
\cline { 2 - 7 } & Total & 2468.417 & 162 & & & \\
\hline
\end{tabular}

Table 5: Coefficient

\begin{tabular}{|c|c|c|c|c|c|c|}
\hline & & \multicolumn{2}{|c|}{ Unstd. Coeff. } & \multirow{2}{*}{$\begin{array}{l}\text { StdCoeff } \\
\text { Beta }\end{array}$} & \multirow[b]{2}{*}{$\mathrm{T}$} & \multirow[b]{2}{*}{ p-value } \\
\hline \multicolumn{2}{|c|}{ Model } & $\mathrm{B}$ & Std. Error & & & \\
\hline \multirow[t]{4}{*}{1} & (Constant) & 12.214 & 1.433 & & 8.522 & .000 \\
\hline & Sales Quotas & 1.246 & .193 & 0.064 & 1.272 & .015 \\
\hline & Social Ties & 4.841 & .588 & 1.103 & 8.239 & .000 \\
\hline & Personal Moral Judgment & -6.096 & .484 & -1.687 & -12.585 & .002 \\
\hline
\end{tabular}

Tables 3, 4 and 5 above present the results of the multiple linear regression analysis showing the effect of sales quotas, social ties, and personal moral judgment on the ethical behaviors of the bank salespeople. The regression model is fit at $R^{2}=60.5 \%$. Overall, the three variables have a significant $\left(F_{\text {cal }}=81.06, p<0.05\right)$ moderating effect as shown on table 4 above. Individually, both Sales Quotas and Social Ties have positive moderating effects whereas, Personal Moral Judgment of the salespeople have a significant negative effect on their ethical behavior (see $\mathrm{B}=-6.096, \mathrm{p}<0.05$ on table 5 above). It means that, there would be low unethical practices where there is high personal moral judgment and vice-versa.

From the foregoing result we reject the null hypothesis $\left[\mathrm{H}_{02}\right]$ and accept alternate hypothesis which states that sales quotas, social ties and personal moral judgment have significant effect on salespeople's ethical behaviours would be accepted.

\section{Hypothesis Three}

$\mathrm{H}_{0}$ :There is no significant congruence between the bank salespeople's and customers' ethical perceptions. $\mathrm{H}_{3}$ :There is significant congruence between the bank salespeople's and customers' ethical perceptions. As the salespeople exhibit their ethical/unethical behaviours there is always a need to check how customers perceive such behaviors. The result is shown on table 6 below.

Table 6: Ethical Congruence between Bank Salespeople and the Customers' Perceptions of Ethical Behaviours

\begin{tabular}{|c|c|c|c|}
\hline & & Customers & Bank Salespeople \\
\hline \multirow{4}{*}{$\begin{array}{l}\text { Customers Perception of } \quad \text { Salespeople } \\
\text { Ethical/Unethical Behavioural Practices }\end{array}$} & Pearson & 1 & $.741^{* *}$ \\
\hline & Correlation & & \\
\hline & Sig. (2-tailed) & & .000 \\
\hline & $\mathrm{N}$ & 122 & 122 \\
\hline \multirow[t]{3}{*}{ Bank Salespeople Ethical/Unethical Practices } & $\begin{array}{l}\text { Pearson } \\
\text { Correlation }\end{array}$ & $.741^{* *}$ & 1 \\
\hline & Sig. (2-tailed) & .000 & \\
\hline & $\mathrm{N}$ & 122 & 122 \\
\hline
\end{tabular}

Table 7: Correlation Matrix

\begin{tabular}{|c|c|c|c|c|c|c|c|}
\hline & & \multicolumn{6}{|c|}{ Bank Salespeople } \\
\hline \multirow{7}{*}{ 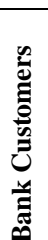 } & & Q1 & $\mathrm{Q} 2$ & Q3 & Q4 & Q5 & Q6 \\
\hline & Q1 & $0.79 * *$ & & & & & \\
\hline & Q2 & & $0.547 * *$ & & & & \\
\hline & Q3 & & & $0.398^{* *}$ & & & \\
\hline & $\mathrm{Q} 4$ & & & & -0.118 & & \\
\hline & Q5 & & & & & 0.407 ** & \\
\hline & Q6 & & & & & & $0.764^{* *}$ \\
\hline
\end{tabular}

**. Correlation is significant at the 0.05 level (2-tailed). 
The results presented on tables 6 and 7 above are the results showing the nature of congruence existing between the ethical behavioural practices of Nigerian bank salespeople and the customer perceptions of such behaviours. From the analysis there is a significant $\left(\gamma=0.741^{* *}, p<0.05\right)$ congruence in the ethical behaviours of bank salespeople and customers' perception of salespeople ethical/unethical behaviour. This means that the ethical/unethical practices of bank Sales force conform to the needs or expectations of most of the customers. Offering of gifts; dating; hanging out/entertainment, chatting are entertained by customers. However, customers detest giving them false information to obtain sales order as indicated on table 7 above [see the ethical congruence coefficient of Q4, $\gamma=-0.118, p>0.05]$.

\section{Hypothesis Four}

$\mathrm{H}_{0}$ :The banks' corporate code of ethics do not have influence on the ethical behaviours of the salespeople.

$\mathrm{H}_{4}$ :The banks' corporate code of ethics have a significant influence on the ethical behaviours of the salespeople.

Table 8: Model Summary

\begin{tabular}{|l|l|l|l|l|}
\hline Model & $\mathrm{R}$ & $\mathrm{R}^{2}$ & Adj. $\mathrm{R}^{2}$ & S.E. of the Estimate \\
\hline 1 & $.275^{\mathrm{a}}$ & .76 & .70 & 3.76415 \\
\hline
\end{tabular}

a. Predictors: (Constant), Ethical Climate; b. Dependent Variable: Ethical Behaviour

Table 9: ANOVA

\begin{tabular}{|l|l|l|l|l|l|l|}
\hline Model & Sum of Squares & Df & Mean Square & F & Sig. \\
\hline \multirow{3}{*}{1} & Regression & 187.239 & 1 & 187.239 & 13.215 & $.011^{\mathrm{a}}$ \\
\cline { 2 - 7 } & Residual & 2281.178 & 161 & 14.169 & & \\
\cline { 2 - 6 } & Total & 2468.417 & 162 & & & \\
\hline
\end{tabular}

Table 10: Coefficient

\begin{tabular}{|c|l|l|l|l|c|c|}
\hline \multirow{2}{*}{ Model } & \multicolumn{2}{|l|}{ Unstandardized Coefficients } & Standardized Coefficients & T & Sig. \\
\cline { 3 - 5 } \multicolumn{2}{|c|}{1} & B & Std. Error & Beta & & \\
\hline & (Constant) & 15.989 & 1.238 & & 12.919 & .000 \\
\cline { 2 - 5 } & Corporate Code of Ethics & -.338 & .093 & -.275 & -3.635 & .010 \\
\hline
\end{tabular}

Tables 8, 9 and 10 above present the results of the regression analysis. The regression model is fit at $\mathrm{R}^{2}$ $=76.0 \%$. Banks' corporate code of ethics has a significant $\left(\mathrm{F}_{\mathrm{cal}}=13.215, p<0.05\right)$ influence on salespeople's ethical behaviours (see table 9). Table 10 shows that, code of ethics has a negative impact on the ethical behaviours of the bank salespeople meaning that the banks' corporate code of ethics is weak. Salespeople's unethical practices is expected to be high. The corporate code of ethics are not strictly followed. Probably, managers do not practice or enforce them which resulted in high unethical behaviours among the salespeople.

\section{Conclusions And Recommendations}

The findings show that there is a significant difference in the ethical practices of the banks' salespeople studied. The First Bank salespeople seem to be more ethical in their dealings with customers than the salespeople of other banks in Nigeria. The ethical practices of the salespeople of new generation banks are similar likewise those of the struggling banks. But overall, the ethical behaviours of all the banks are not shaped alike. The study further revealed that allocation of difficult sales targets/quota; strong social ties between salespeople and customers as well as the level of personal moral judgment of the salespeople, have significant moderating effect on their ethical behaviours. These are the major reasons for high unethical behaviours among the sales force. Surprisingly, however, findings show that customers seem to show approval for unethical behaviours observed among the salespeople such as offering of gifts, dating and chatting with customers at odd hours, hanging out and entertainments of customers are approved by the customers except giving misleading information to customers to induce sales. Since customers show interest in the seemingly unethical behaviours of the salespeople, these unethical conducts are more likely to increase customers buying intentions. This finding is quite inconsistent with many other similar studies where unethical behaviours are shown to have negative effect on sales performance (Churchill et al 1997).

This study also shows a negative impact between the banks' code of ethics and salespeople's ethical behaviours. This means that the ethical standards of most of the banks are weak either because they are not practiced or enforced by managers. Overall, although not conspicuously written in banks' code of ethics, managers and salespeople seem to believe that some unethical behaviours are necessary to close a sale. Not paying bribes/ gifts either in cash or kind might put them or their firms in a competitive disadvantage and customers seem to consent to these. These acts seem profitable in the short-run however in the long-run they may damage the reputation of the bank in question. This study is a case of ethical dilemma. It would probably 
be ideal to recommend that Nigerian bank managements and their regulatory institution, i.e. the Central Bank of Nigeria $[\mathrm{CBN}]$ should adopt a discretional measure in approaching this growing phenomenon.

\section{References}

[1]. Adnan, A., Saher, N., Naureen, H., Qureshi, S., and Khan, N.Y. (2013). What Shapes EthicalBehaviour of Sales Team? A Case Study of Banking Sector of Pakistan. Interdisciplinary Journal of Contemporary Research Business, 5(1): 424 - 442

[2]. Agarwal, J., and Malloy, D.C. (2009). Ethical Work Climate Dimensions in a Not-for-Profit Organization: An Empirical Study. Journal of Business Ethics, 67(8): 1 - 14

[3]. Akenbor, C.O and Imade, S. (2011), Sales Tragets and Ethical Behaviour of Marketing Executives in the Nigerian

[4]. Banking Industry; An International Multi-Diciplinary Journal, Ethiopia, 5 (3) 212-225.

[5]. Badovick, G.J. (2010). "Emotional Reactions and Salesperson Motivation: An Attributional Approach Following

[6]. Inadequate Sales Performance", Academy of Marketing Science, 18(2): 123-131.

[7]. Baker, M. J. (2008) Relationship Marketing in Three Dimensions. Journal of InteractiveMarketing, 24(1):47 - 62

[8]. Berry, L. L. (2005). Relationship Marketing of Services--Growing Interest, EmergingPerspectives. Journal of the Academy of Marketing Science, $236-245$

[9]. Bharadwaj, S. G. (2004). Relationship Marketing: Theory, Methods and Applications). AtlantaGA: Emory University Center for Relationship Marketing.

[10]. Biong, H., Parvatiyar, A., and Wathne, K. (2006). Are Customer Satisfaction MeasuresAppropriate to Measure Relationship Satisfaction? Marketing Review, 24(2): 258 - 275

[11]. Borys, B., and Jemison, D. B. (2009). Hybrid Arrangements as Strategic Alliances: TheoreticalIssues in Organizational Combinations. Academy of Management Review, 8(1): 234-249

[12]. Brower, H.H., and Shader, C.B. (2000). Moral Reasoning and Ethical Climate: Not-for-Profit vsFor-Profit Boards of Directors. Journal of Business Ethics, 26(3): 147 - 167

[13]. Butler, J. (1996), Marketing Relations, London Pitman Publishing

[14]. Churchill, G.A; Jr, Ford, N.M and Walker, O.C; Jr, (1997) "Sales Force Management", 5" edition, U.S.A: Richard .D. Irwin.

[15]. Cotte, J., Trudel, R.J., and Ly, C. (2006), Ethical Climate: Management's Role in UnethicalSales force Behaviour. Administrative Sciences Association of Canada, $182-197$

[16]. Cullen, J.B., Parboteeah, K., and Victor, B. (2003). The Effects of Ethical Climates onOrganizational Commitment: A Two-Study Analysis. Journal of Business Ethics, 46(5): 127 - 141

[17]. DeConinck, J.B. (2003). The Impact of a Corporate Code of Ethics and Organizational Justice onSales Managers' Ethical Judgments and Reaction to Unethical Behaviour. Marketing Management Journal, 13(2): 23 - 31

[18]. Dick, A. S., and Basu, K. (2004). Customer Loyalty: Toward an Integrated ConceptualFramework. Journal of the Academy of Marketing Science, 22: 99 - 113

[19]. Futrel, C (2003), Fundamentals of Selling, $7^{\text {th }}$ edition, Homewood Boston, U.S.A: Richard D. Irwin

[20]. Gronroos, C. (2010). Relationship Approach to Marketing in Service Contexts: TheMarketing and Organizational Behavior Interface. Journal of Business Research, 20(4): 3-11

[21]. Hunt.S.D andVitell, S (1986), A General Theory of Marketing Ethics, Journal of Macro- Marketing, Spring, 5-16

[22]. Jobber, D and Lancaster, G (2009), Selling and Sales Management, $8^{\text {th }}$ edition, England: Pearson Education Ltd.

[23]. Nebo, G.N (2016), Management of Personal Selling, $2^{\text {nd }}$ edition Enugu: Immaculate Publications

[24]. Nunnally, J. C., and Bernstein, I. H. (1994), Psychometric theory (3rd ed.). New York: McGraw-Hill in Lacobucci, D., and Duhochek, A. (2003). Advancing Alpha: Measuring Reliability with Confidence Journal of Consumer Psychology, 13(4), 478 - 487

[25]. Ojikutu, R.K., Obalola, M.A., and Omoteso, K. (2013). Assessing the Relationship betweenSales Quotas and Moral Judgment of Insurance Salespersons: The Moderating Effects of Personal Moral Values, Quota FailureConsequences, and Corporate Ethical Climate. Journal of Emerging Trends in economics and Management Sciences, 4(2): 274 - 288

[26]. Seevers, M.T., Skinner, S.J., and Kelley, S.W. (2010). A Social Networks Perspective onSales Force Ethics. Keller Centre Research Report, September.

[27]. Spiro, R.L; Stanton, W.J; and Rich, G.A (2003), Management of Sales Force, $11^{\text {th }}$ ed., New Delhi: Tata McGraw-Hill Publishing Company Limited.

[28]. Weeks, W.A., and Nantel, J. (1992). Corporate Codes of Ethics and Sales Force Behaviour: ACase Study. Journal of Business Ethics, 11: $753-760$ 